\title{
Is the Aftershock Zone Area a Good Proxy for the
}

8 Questions can be directed to neoj@umich.edu

9 This paper is a preprint submitted to EarthArXiv. It has been accepted by the Bulletin of Seismological Society

10 America (BSSA) and is pending publication

\section{Mainshock Rupture Area?}

\author{
Jing $\mathrm{Ci} \mathrm{Neo}{ }^{1}$, Yihe Huang ${ }^{1}$, Dongdong $\mathrm{Yao}^{1}$, Shengji Wei ${ }^{2}$
}

[1] University of Michigan, Ann Arbor. 1100 North University, Room 4534F, neoj@umich.edu

[2] Asian School of the Environment, Nanyang Technological University. Earth Observatory of Singapore, 50

Nanyang Avenue, Block N2-01a-15

11 
12 Abstract The locations of aftershocks are often observed to be on the same fault plane as the

13 mainshock and used as proxies for its rupture area. Recent developments in earthquake relocation

14 techniques have led to great improvements in the accuracy of earthquake locations, offering an unprecedented opportunity to quantify both the aftershock distribution and mainshock rupture area. In this study, we design a consistent approach to calculate the area enclosed by aftershocks of $12 \mathrm{Mw} \geq 5.4$ mainshocks in California, normalized by the mainshock rupture area derived from slip contours. We also investigate the Coulomb stress change from mainshock slip and compare it to the aftershock zone. We find that overall, the ratios of aftershock zone area to mainshock rupture area, hereinafter referred to as "aftershock ratio", lie within a range of 0.5 to 5.4 , with most values larger than 1. Using different slip inversion models for the same mainshock can have a large impact on the results, but the ratios estimated from both the relocated catalogs and Advanced National Seismic System (ANSS) catalog have similar patterns. The aftershock ratios based on relocated catalogs of Southern California fall between 0.5 and 4.3, while they exhibit a wider range from 1 to 5.4 for Northern California. Aftershock ratios for the early aftershock window (within 1 day) show a similar range but smaller values than using the entire aftershock duration, and we propose that continuing afterslip could contribute to the expanding aftershock zone area following several mainshocks. Our results show that areas with positive Coulomb stress change scale with aftershock zone areas, and spatial distribution of aftershocks represents stress release from mainshock rupture and continuing postseismic slip.

\section{Introduction}

32 Beginning in the 1930s, scientists believed that aftershock zone area corresponds to the area where strain is accumulated and released during an earthquake sequence (Utsu, 1969). However, large uncertainty in earthquake location and the lack of slip models in early studies prevented scientists

35 from verifying this hypothesis (Das and Henry, 2003). With the advent of modern slip models and 36 large increase in the amount of seismic data, studies have qualitatively examined the aftershock 
37 distribution of large earthquakes with respect to mainshock slip areas. They found that early

38 aftershocks (within the first 24 hours) tend to occur on the periphery of the eventual aftershock

39 zone, and the region in the center of the zone corresponds to the extent of the coseismic rupture

40 area (C. Mendoza and Hartzell, 1988; Dietz and Ellsworth, 1990; Oppenheimer, 1990; Das and

41 Henry, 2003). However, in spite of the wealth of literature on aftershock distribution, there has

42 been a dearth of studies that quantify the relationship between the aftershock zone area and the

43 mainshock rupture area, both immediately after the mainshock and over time. Recent

44 developments in seismological techniques have led to great improvements in the accuracy of

45 earthquake locations and finite fault solutions, and provided an unprecedented opportunity to

46 characterize the aftershock zone and the mainshock rupture using the latest earthquake catalogs

47 and slip models.

48 A better characterization of aftershock distribution is also the foundation for understanding the

49 underlying mechanisms of aftershock generation. Different mechanisms have been used to explain

50 the differences in aftershock distribution: static stress change, postseismic deformation, and

51 transient dynamic stress change (Freed, 2005). Transient dynamic stress change can be used to

52 account for earthquakes up to thousands of kilometers away (Belardinelli et al., 2003; Van Der

53 Elst and Brodsky, 2010; Parsons and Geist, 2014; Fan and Shearer, 2016), but due to the large

54 distances involved it is not relevant to this study. Static stress change is the stress change in the earth's crust surrounding the fault planes due to slip on the faults (King et al., 1994, etc.). In particular, Coulomb stress change became popular in the past few decades with numerous studies attempting to correlate static Coulomb stress change with aftershocks (King et al., 1994; Stein et al., 1997; Hardebeck et al., 1998; Toda et al., 1998, 2011; Kilb et al., 2002; Marsan and Lengliné,

592010 , etc). Many of these studies found that the distribution of the aftershocks appears to be colocated with regions of positive Coulomb stress change. 
61 However, not all studies agree that static stress change is the only predictor of aftershock

62 distribution, especially the temporal evolution of aftershocks (Cattania et al., 2015). By

63 investigating over two hundred slip inversions, Meade et al. (2017) found that other stress change

64 components such as max shear stress and stress invariants, or postseismic deformation such as

65 afterslip/postseismic relaxation may account for the spatial distribution of aftershocks better. Both

66 afterslip and viscoelastic relaxation have been shown to be able to explain aftershock distribution

67 (Pollitz et al., 1998; Diao et al., 2014). For example, Perfettini and Avouac, $(2004,2007)$ found

68 that the aftershocks of the 1999 Chi-Chi earthquake and the 1992 Landers earthquake correlate

69 well with afterslip in both space and time. Savage et al., (2007) concluded that fault creep alone is

70 insufficient to explain the postseismic deformation and aftershocks of those earthquakes, thus

71 viscoelastic relaxation has to be considered.

72 In this study, we design a consistent approach to calculate the aftershock zone area and estimate

73 its relationship with the mainshock rupture area for both early aftershocks and the whole aftershock

74 duration. This approach applies the beta statistic (Matthews and Reasenberg, 1988) to provide a

75 more universal criterion to estimate the aftershock duration and aftershock boundary, which are

76 key factors in the calculation of the aftershock zone area and were previously determined upon

77 certain empirical assumptions. We select recent moderate to large $(\mathrm{Mw} \geq 5.4)$ mainshocks in

78 California that have both relocated aftershocks and resolved slip inversion models (Figure 1). To

79 further understand the aftershock generation mechanism, we also compute the static Coulomb

80 stress change from mainshock slip and compare it with the aftershock zone area. Meanwhile, we

81 compile published works on afterslip models and discuss their roles in modulating the aftershock

82 distribution.

\section{Data and Method}


84 We choose 12 moderate-to-large $(\mathrm{Mw} \geq 5.4)$ earthquakes in California as candidate mainshocks

85 (Figure 1). The slip inversion models are obtained from the Finite-Source Rupture Model Database 86 (SRCMOD) (see Data and Resources Section). We use both relocated catalog (either double87 difference or waveform relocated) and Advanced National Seismic System (ANSS) catalog for 88 following analysis. The relocated catalogs generally have better relative locations. However, a certain percentage of earthquakes might be dropped during the relocation process and potentially affect seismicity rate estimation. The ANSS catalog includes all archived earthquakes but endures relatively larger location error. We include both catalogs to evaluate the consistency. More specifically, the double-difference catalogs are acquired from the Northern California Earthquake Data Center (NCEDC) (Waldhauser and Schaff, 2008; Waldhauser, 2009). Waveform relocated catalogs are obtained from the Southern California Earthquake Data Center (SCEDC) (Hauksson et al., 2012). We download earthquakes that occurred up to 1 year before and after each mainshock within the surrounding area. We use an area that is deliberately much larger than needed to avoid creating an artificial upper limit when calculating the aftershock zone area. A grid of \pm 1 -degree latitude and longitude relative to the mainshock epicenter is used to download earthquakes from NCEDC/SCEDC, while a circle with a radius of five times the source dimension is used to download earthquakes from the ANSS catalog.

\section{Earthquake Selection}

102 To choose earthquakes associated with mainshock faults, only earthquakes with off-fault distances

103 less than $2 \mathrm{~km}$ to the fault plane from the slip inversion are kept for further analysis. We use $2 \mathrm{~km}$

104 because earthquake epicenter location uncertainties typically fall within $2 \mathrm{~km}$. We have tried different off-fault distances from 1 to $20 \mathrm{~km}$ and find that off-fault distances below $5 \mathrm{~km}$ do not show a large difference. As hypocenter locations given by the slip inversion data and the catalogs

107 are slightly different, we shift earthquake locations in the catalog using the hypocenter in the slip 108 inversion as a reference for some mainshocks. This ensures that the selection of earthquakes by 
off-fault distance is accurate and does not affect the calculation of the aftershock zone area. The

110 fault planes are extrapolated past each end, and the earthquakes are then projected onto the nearest

111 fault plane (i.e., smallest fault-normal distance).

\section{Magnitude of Completeness}

113 To remove bias in calculating the change in seismicity rate, we need to ensure that the catalog is 114 complete for both the periods before and after the mainshock, i.e. there are no missing earthquakes

115 for the magnitude range we use. Hence, we calculate the magnitude of completeness (Mc) for both

116 time periods, and only earthquakes with magnitudes above the larger Mc are used. In a few cases,

117 Mc cannot be calculated for either before or after the mainshock, due to the sparsity of data or the

118 shape of the magnitude-frequency distribution (MFD). Hence, we use Mc of the time period that

119 can be calculated instead. The most straightforward way of calculating Mc is the maximum

120 curvature method, which often underestimates Mc for gradually curved bulk MFDs. The Mc95

121 and Mc90 methods, which calculate the lowest Mc value that gives a best fit of 95\% and 90\%,

122 provide a closer estimate, but sometimes Mc cannot be calculated when the MFD curve never

123 reaches a $90 \%$ fit. Hence, we use the best combination method, whereby an initial estimate is

124 calculated using the max curve, and then the algorithm searches for the Mc95 value and Mc90

125 value in a fixed range around the estimate. These methods are described thoroughly in Mignan and

126 Woessner (2012), and we use the open-source MATLAB code written by Schorlemmer and

127 Woessner (2004) to calculate Mc (see Data and Resources Section). We set the magnitude bin size

128 to be 0.1 and do not apply any correction.

\section{Beta Statistic: A measure of change in seismicity rate}

130 The $\beta$-statistic quantifies seismicity rate change based on the difference between the observed and

131 expected number of events occurring in a time period, normalized by the standard deviation of the 132 expected value (Kilb et al., 2000; Aron and Hardebeck, 2009). The standard deviation is calculated 
133 by assuming a binomial distribution where earthquakes occur either inside or outside the time

134 period Ta (Matthews and Reasenberg, 1988). A $\beta$ value of 2, which means 95\% significance of

135 increase in seismicity when the $\beta$ value is normalized by its standard deviation, is used as the

136 threshold to determine if there is a significant increase in seismicity. The equation to calculate the $137 \beta$ value is shown below (Equation 1).

$$
\beta=\frac{N_{a}-N * T_{a} / T}{\sqrt{N\left(T_{a} / T\right)\left(1-T_{a} / T\right)}}
$$

Where $\mathrm{Na}$ is the number of events in the time period of interest, $\mathrm{N}$ is the number of events in the entire time period, $\mathrm{Ta}$ is the duration of the time period of interest and $\mathrm{T}$ is the duration of the entire time period (background window duration $\mathrm{Tb}$ plus above defined $\mathrm{Ta}$ ).

\section{Defining Aftershock Zone}

Determining aftershock zone area is difficult as aftershocks can occur over a large and continuous area especially in places with high background seismicity such as Parkfield, and deciding which earthquakes constitute aftershocks can be quite challenging. Methods used by previous studies include fitting ellipses (Utsu, 1969), drawing energy contours (Tajima and Kanamori, 1985), terminating the aftershock zone based on gaps between the earthquakes (Meng and Peng, 2016), or drawing a simple boundary around the aftershocks (Sykes, 1971). We use the $\beta$-statistic to calculate the aftershock zone area by defining the aftershock zone as the region with significant increase in seismicity rate after the mainshock. To find the aftershock zone, we create a grid for the fault plane and the surrounding regions and calculate the $\beta$ value for each grid cell. A convex boundary is then drawn around those areas with significant change in seismicity using the MATLAB function "boundary" with a 'shrink factor' of 0 , which is consistent with results using Delaunay triangulation to denote the boundary. The area enclosed by the boundary is then taken to be the aftershock zone area. Another possible method of calculating the aftershock area is to add up area of cells with significant seismicity rate increase. However, we choose not to use this 
method mainly because the aftershock zone area increases with cell size, which could be subjective

159 to provide a consistent way to estimate aftershock zone area spanning different magnitudes (Figure

$160 \mathrm{~S} 1)$. In comparison, drawing a boundary around the aftershocks is a robust way to define the

161 aftershock zone area that is largely unaffected by cell size (Table S1). Figure 2 illustrates the

162 calculation of the aftershock zone area. Previous calculations of $\beta$ values have used different cell 163 sizes such as $2 \mathrm{~km}$ (Aron and Hardebeck, 2009) and $6 \mathrm{~km}$ (Kilb et al., 2000). As earthquakes are 164 represented as points in the grid, the choice of cell size has an impact on the $\beta$ values. Using 165 different cell sizes that range from 1 to $4 \mathrm{~km}$, we find that as long as the cell size is large enough 166 such that each earthquake is not isolated, the pattern of $\beta$ values remains similar. However, a larger 167 cell size like 6 by $6 \mathrm{~km}$ (Kilb et al., 2000) is not appropriate as it is close to the rupture length of the mainshock, which ranges from 9 to over $100 \mathrm{~km}$ in our analysis. Hence, we use a cell size of

1692 by $2 \mathrm{~km}$. We locate the areas where the $\beta$ value is larger than 2 and terminate the aftershock 170 zone area when there is a gap larger than $15 \mathrm{~km}$ (Meng and Peng, 2016). We test a range of gap 171 sizes from 5 to $20 \mathrm{~km}$ and find that for small off-fault distances $(\leq 5 \mathrm{~km})$, and the gap size does not 172 affect the results.

173 The choice of time periods $\mathrm{T}$ and Ta (as in Equation 1) can greatly affect the calculation of the 174 aftershock zone area by controlling the number of earthquakes that constitute change in seismicity rate. To estimate the background seismicity rate, we adopt a long-term averaged rate before the mainshock. Previous studies reported obvious increasing foreshocks before some large 177 earthquakes (Dodge et al., 1995; Hauksson et al., 2002, etc). However, the short-term foreshock 178 activity should not significantly impact our calculation since we use a much longer window before 179 the mainshock. To test this, we use background window lengths of one year and two years and 180 find that the ratios are generally consistent except for the Whittier Narrows and North Palm Springs 181 earthquake (Figure S2). The range of ratios also remain the same using both pre-shock windows. 182 Since using a pre-shock duration of one year generates more consistent results between the 
relocated and non-relocated catalogs, we use a pre-shock duration of one year to calculate $\beta$ values

184 and aftershock zone areas.

\section{Defining Aftershock Duration}

186 Scientists have previously pointed out that there was no formal agreement on a consistent space187 time windowing algorithm to select aftershocks (Knopoff et al., 1982), which is still true to this 188 date. The choice of aftershock duration is complicated by the fact that the aftershock zone area 189 could expand with time (Tajima and Kanamori, 1985), and different mechanisms could tangle

190 together with longer durations. Different aftershock durations ranging from one day (Kanamori, 191 1977), weeks (Wetzler et al., 2018) to years (Parsons, 2002; Perfettini and Avouac, 2007) have

192 been used, depending on the need of each study. Some studies suggested that earthquakes may still 193 have aftershocks decades or centuries later (Bouchon et al., 2013; Ebel and Chambers, 2016). Here

194 we define aftershock duration as the time period when there is still a significantly elevated rate of 195 seismicity in the region. We then calculate the sliding-window $\beta$ value for the entire faulting 196 system (fault plane and the extended regions) using the aftershocks within an off-fault distance of $1972 \mathrm{~km}$, with $\mathrm{N}$ in equation (1) equal to all the earthquakes that occurred in the region and Ta equal 198 to 10 days after the mainshock. We then slide the time window with a time interval of 5 days and 199 track the evolution of the $\beta$ value through time. The entire aftershock duration is given by the first 200 time-window when the $\beta$ value drops below the threshold value of 2 . The aftershock duration gives 201 Ta, the time period of interest used in the calculation of the $\beta$ value in each grid cell. The aftershock duration can vary between a few weeks and over a year (Figure 3).

\section{Aftershock Ratio}

204 The coseismic rupture area is defined as the area enclosed by a contour of 0.15 of the maximum 205 slip (Wetzler et al., 2018). A slip contour is used because areas with very low slip may not be well resolved and depend greatly on the smoothing method used in the kinematic source inversion. 
207 Hence, we also estimate the uncertainty from the slip models by calculating rupture areas with slip 208 contours of 0.1 and 0.2 of maximum slip. We then calculate the ratio of the aftershock zone area

209 to the coseismic rupture area to investigate how well the aftershock zone area approximates the

210 rupture area. Since each earthquake model is unique, some of them require special processing

211 procedures as listed in Table S2.

\section{Coulomb Stress Change Area}

213 In order to examine how the mainshock slip impacts the aftershock zone area, we utilize the

214 Coulomb 3 software to calculate the resulting Coulomb stress change of each earthquake (King et

215 al., 1994). We use the entire slip model and the orientation of the main fault plane as the receiver

216 fault to find the Coulomb stress change of the region. Assuming that earthquakes below a certain

217 off-fault distance lie on the same fault plane as the mainshock, we use the orientation of the main

218 fault plane as the receiver fault to find the Coulomb stress change of the region. We also use a

219 friction coefficient of 0.6 , although faults have a large range of plausible values between 0 to 0.75

220 (King et al., 1994). The cross-section of the fault and its surrounding region are calculated with a cell size of 1 by $1 \mathrm{~km}$. We test thresholds of 0.1 and $1 \mathrm{MPa}$ and find that both will result in a similar trend, but the area enclosed by the $1 \mathrm{MPa}$ cells are more similar to the aftershock zone area observed from the $\beta$-statistic. Hence, we sum the area of the cells that have a positive Coulomb stress change of $1 \mathrm{MPa}$ or more to compare with the aftershock zone area (Figure 4). The results of our Coulomb stress change calculations are listed in Table S3.

\section{Results}

227 We analyze a total number of $12 \mathrm{Mw} \geq 5.4$ California mainshocks (Table 1), with 3 events from the NCEDC double-difference catalog and the rest from the SCEDC waveform relocated catalog. Most of them are strike-slip events, except for the 1994 Northridge earthquake with a thrust mechanism and the 1989 Loma Prieta earthquake with an oblique mechanism. We calculate the 
231 aftershock ratio of each mainshock, often for multiple slip inversion models (Figure 5). The

232 parameters that we used are summarized in Table S4. We also list the data types used by each slip

233 model in Figure 5. Strong ground motion data are predominantly used for Northern California

234 (NC) earthquakes, while various data types are used for Southern California (SC) earthquakes.

235 We find that aftershock zone areas are within a range of 0.5 to 5.4 times of the mainshock rupture

236 area (Figure 6). Some earthquakes such as the 1989 Loma Prieta earthquake have consistently

237 higher ratios, while others such as the 1999 Hector Mine earthquake and the 1994 Landers

238 earthquake have consistently lower ratios. We explore their potential causes further in the

239 Discussion section. Ratios of the same earthquake estimated from different slip inversion models

240 can vary widely. For example, the ratio for the Gallovič (2016) model of the 2014 South Napa

241 earthquake is more than 3 times of the ratio for the Wei et al. (2015) model. This is partially

242 because the Wei et al. (2015) model has a slip area that is twice as large as the Gallovič (2016)

243 model. The two slip models also assume significantly different fault planes. Since only earthquakes

244 within $2 \mathrm{~km}$ of the fault planes are included as potential aftershocks, the aftershock zone area

245 estimated for Wei's model is smaller than that for Gallovič's model. Our results also show a similar

246 pattern between the ratios estimated from the ANSS and relocated earthquake catalogs. Table 2

247 shows that both types of catalogs have almost identical average ratios, but the ANSS catalog has

248 larger variance. We also note that the ratios for 2012 Brawley and 1987 Elmore Ranch earthquakes

249 differ by a factor of 2 across the relocated and ANSS catalogs. The similar ratios estimated from

250 different catalogs demonstrate that aftershock zone area is a macroscopic source feature that is not

251 sensitive to the differences of earthquake locations in catalogs. We do not observe a clear

252 correlation between moment magnitudes and aftershock ratios either (Figure S3).

253 Early Aftershock Zone 
254 Above results are based on the entire aftershock duration. Since different aftershock generation mechanisms could affect the long-term aftershock evolution, we also measure ratios using only

256 early aftershocks to exclude postseismic deformation if existed. The early aftershock window is 257 set as 1-day after the mainshock (Kanamori, 1977) and the results are shown in Figure 7. Since the $258 \mathrm{Ta} / \mathrm{T}$ term is close to 0 in our study, every single earthquake in each cell after the mainshock would 259 be significant in the output beta value. Hence, only the off-fault distance, gap size and Mc are used to determine which aftershocks to include in the analysis. Generally, the ratios for the 1-day

261 duration are smaller than or equal to those for the entire aftershock duration. But the range of ratios $262(0.5-3.5)$ is comparable to the range for the entire aftershock duration (0.5-5.4). The early 263 aftershock ratios are listed in Table S5 and statistics of the ratios are shown in Table 2.

\section{Static Stress Change}

265 If aftershocks are primarily triggered by the Coulomb stress change, they should occur within the 266 area with the positive Coulomb stress change. Hence, we compare the positive Coulomb stress 267 change area and the aftershock zone area of each mainshock (Figure 3). We find that the Coulomb 268 stress change area shows a positive correlation with the aftershock zone area (Figure 8), which may support the hypothesis of static stress change being a triggering mechanism for aftershocks. However, this correlation does not necessarily mean causation. Alternatively, the correlation may indicate that both static stress changes and aftershock areas are related to certain mainshock source

272 parameters. The correlation between the Coulomb stress change and the aftershock zone area is 273 not an ideal linear trend either, and the discrepancies may be due to the uncertainty from coseismic 274 slip models and the inclusion of other aftershock triggering mechanisms. In particular, the Loma 275 Prieta aftershock zone area appears to be an outlier, as its aftershock zone area is much larger than 276 that of the other earthquakes given its relatively small Coulomb stress change area. We also show 277 the ratio of Coulomb stress area to aftershock area with magnitude (Figure 9), and the results are 

inconclusive, with either a slight increase or no change in ratio with magnitude depending on the

279 fitting method used.

\section{Discussion}

281 The value of the aftershock ratio can help reveal important characteristics of the region such as 282 aftershock mechanisms in play, but it cannot be used to precisely predict the mainshock rupture 283 area. One should be careful about drawing conclusions about the rupture area from the aftershock 284 zone area, as (1) there is a broad range of aftershock ratios, (2) even if the ratio is close to 1 , the spatial distribution of the aftershocks with respect to the mainshock rupture area may still be different and (3) the aftershock ratios are based on California earthquakes and likely to differ even more for earthquakes outside California. In this section, we discuss the potential causes of large variations in aftershock ratios, including different aftershock mechanisms and uncertainties introduced during our calculations. To further test the method, we also conduct similar analysis on the 2011 Virginia earthquake outside California. Given the large difference in crustal structure between California and the eastern U.S., the Virginia earthquake serves as an extreme contrast to California earthquakes.

\section{Comparison to a non-California earthquake: An example from the Eastern U.S.}

294 We analyze the 23 August 2011 M5.7 Mineral, Virginia earthquake using the slip model from 295 Chapman (2013) and double-difference relocated earthquakes from Wu et al. (2015). We do not use the ANSS catalog that has very few earthquakes over two years $(\sim 54)$. Since the doubledifference catalog only has earthquakes starting from $25^{\text {th }}$ August 2011, we cannot calculate

298 aftershock duration, 1-day aftershock zone area or Mc of the background seismicity. Here we 299 assume an aftershock duration of one year and obtain an aftershock ratio of 14.1 for aftershocks within an off-fault distance of $2 \mathrm{~km}$ (Figure S4). The ratio of the aftershock zone area to the

301 Coulomb stress change area is 14.3. Since the result is subject to the unknown Mc and uncertainty 
in aftershock duration, we also investigate their effects by varying Mc in the range of 0 and 1 (the catalog has an Mc of 0) and changing aftershock durations between 5 and 365 days. We find that

304 the aftershock ratio is still much larger than the ratios we obtained for the Californian earthquakes.

305 The aftershock ratio of 14.1 for the Virginia earthquake is $\sim 3-28$ times as large as the ratios we 306 obtained for Californian earthquakes, and the disparity cannot be explained by Coulomb stress 307 change. One possible reason for the large aftershock ratio may be because of the unusually high 308 stress drops of the mainshock (Wu and Chapman, 2017). The high stress drop may have led to a

309 smaller rupture area than California earthquakes with the same magnitude, while the aftershock 310 zone area remains typical for a M5.7 mainshock. This example suggests that aftershock ratios may 311 depend heavily upon tectonic environment and the resulting differences in earthquake 312 characteristics.

\section{Afterslip: An alternative aftershock mechanism}

314 As Coulomb stress change cannot satisfactorily explain the large aftershock zone area of the Loma

315 Prieta mainshock, an alternative mechanism for aftershock generation is afterslip following the

316 mainshock. The variation of geologic conditions in California results in different amounts of

317 afterslip for each earthquake. The central part of the San Andreas Fault exhibits large amounts of 318 aseismic creep (Khoshmanesh and Shirzaei, 2018), whereas the southern portion is locked with 319 significant slip deficit (Fialko, 2006). Though the underlying reason is not well known, some 320 studies suggest that it might be due to the presence of serpentinite at creeping faults in Northern and Central California (Moore and Rymer, 2007). Studies have shown that the Loma Prieta earthquake has afterslip extending around 40-60km towards the southeast along the San Andreas

323 fault (Behr et al., 1990; Pollitz et al., 1998). The shallow afterslip (above 15km depth) was found

324 to have most likely occurred on the Loma Prieta fault (Bürgmann et al., 1997). Although the 325 afterslip was found to be relatively small (less than $1 \mathrm{~cm}$ over 4 months), the afterslip area roughly 
corresponds to the aftershock zone area in our analysis, which extends southwards for $60 \mathrm{~km}$ from

327 the mainshock rupture in a shallow region above $15 \mathrm{~km}$ depth. Hence, we argue that the afterslip

328 could account for the large aftershock zone area of Loma Prieta.

329 Afterslip can occur in the surrounding region loaded by mainshock rupture and transfer stresses

330 on faults that promote the generation of aftershocks. It is unfeasible to quantitatively evaluate the

331 contribution by Coulomb stress change and other mechanisms without detailed rupture simulation

332 based on realistic parameters. For mainshocks with observed afterslip, a combination of the static

333 stress change and afterslip instead of the Coulomb stress change alone could contribute to the

334 positive correlation between the Coulomb stress change area and the aftershock zone area. By

335 comparing the ratios from using both entire aftershock duration (Figure 6) and early aftershocks

336 (Figure 7), we observe that the long-term aftershock duration results in relatively larger ratio for

337 the South Napa, Loma Prieta, Brawley, Joshua Tree, Elmore Ranch and Whittier Narrows

338 earthquakes. The larger ratio could be explained by expanding aftershock zones with time caused

339 by postseismic deformation process. In contrast, similar range of aftershock ratios for the other

340 earthquakes support that Coulomb stress change caused by the mainshock rupture plays an

341 important role in aftershock distribution.

342 We also search for published work on postseismic slip following the studied mainshocks, and

343 seven earthquakes have resolved postseismic slip model (Table S6). For most earthquakes

344 analyzed in the table, the afterslip distribution is similar in extent to our aftershock zone area

345 though their depths may be different, which is consistent with emerging evidences that afterslip

346 could affect the long-term aftershock evolution (Perfettini et al., 2018). To better understand the

347 outlier mainshocks, we could potentially use afterslip models to measure the stress change caused

348 by afterslip, similar to that of Perfettini and Avouac $(2004 ; 2007)$, to ascertain if it correlates better

349 with their aftershock zone areas. This exceeds the scope of this study and could be a potential work

350 in future with more available afterslip models. 
352 The measurement uncertainties in our calculations include the (1) earthquakes locations, (2) the calculation of Mc, (3) the assumption of threshold $\beta$ value, (4) the upper limit of the grid and gap size, (5) slip inversion results, and (6) the assumption that the fault plane extends in roughly the same plane outside of the mainshock rupture area.

As shown by the large variations of ratios for different slip models, slip inversion results probably contribute to the largest uncertainty in this study. Thus, we estimate the uncertainty by calculating rupture areas defined by 0.1 and 0.2 of the maximum slip (Table S7), which is shown as error bars in Figures 6 and 7. The results show that the aftershock ratios of 2014 South Napa and 1986 North

360 Palm Springs earthquakes may be biased by slip models that have large uncertainty. Aside from the slip contours, other sources of error from the slip models include the slip inversion parameters used, such as the geometry and orientation of the fault planes, but they are much harder to quantify.

363 We also examined the uncertainty of earthquake locations for the Parkfield mainshock using the Ji (2004) model. We use location uncertainties of $0.5 \mathrm{~km}, 1 \mathrm{~km}$ and $2 \mathrm{~km}$ to randomly vary the locations of all the aftershocks. We generate 10,000 synthetic distributions of aftershocks and find

366 the standard deviations of aftershock zone areas are $0.09,0.12$ and 0.15 respectively, which is 367 about 4.8 to $7.8 \%$ of the mean value. As the location uncertainties for most earthquakes are smaller than $2 \mathrm{~km}$, we believe that the location uncertainty will not greatly affect the ratios.

369 We calculate Mc before and after the mainshock and remove earthquakes below Mc. Though this 370 procedure ensures that the seismicity change is not biased by the incomplete catalog, it also removes earthquakes from consideration, which may cause the calculated aftershock zone area to

372 be smaller than the real aftershock zone area. To estimate the impact of removing earthquakes

373 below Mc, we calculate the aftershock zone areas of the Brawley and El Mayor-Cucapah 374 mainshocks using the Quake Template Matching (QTM) Catalog for Southern California (Ross et 
375 al., 2019) that has a much lower Mc due to the new detections. The ratios of aftershock zone areas

376 to mainshock rupture areas estimated from this catalog are larger than that calculated from the

377 relocated SCEDC catalog (Table S8, Figure S5). However, they are still within the range of ratios

378 (0.5-5.4) obtained for all the mainshocks.

379 We limit the calculation of the aftershock zone area by setting a threshold $\beta$ value of 2 . A threshold

380 value of 2 indicates $95 \%$ significance of increase in seismicity when we normalize the $\beta$ value by

381 its standard deviation. The assumption behind the calculation of standard deviation is that each

382 earthquake is an independent event and the probability of an earthquake occurring at any given

383 time is equal. This may not be a valid assumption for earthquakes as the probability of having

384 earthquakes after a mainshock is much higher than before the mainshock, but all metrics for

385 determining aftershock zone area necessarily contain arbitrariness.

386 We also set an upper limit of the spatial grid and gap to terminate aftershock zone, which is many

387 times of the source dimension but may still violate the observation of the so-called "global

388 aftershock zone" (Parsons and Geist, 2014; Johnson and Bürgmann, 2016). Among our 389 investigated mainshocks, we noticed an increase of microearthquakes within the Geysers 390 geothermal region following the 2014 Napa earthquake (Figure 2), likely triggered by the passing

391 seismic waves (Meng et al., 2014). More recently, Ross et al. (2019) suggested that the $2010 \mathrm{El}$

392 Mayor-Cucapah earthquake widely triggered events in Southern California. Hence, we are

393 referring to the traditional aftershock zone in this study, where various triggering mechanisms are 394 comparable.

\section{Other Results}

396 Studies have shown that aftershocks tend to be concentrated around the boundary of the mainshock

397 rupture zone, with a deficit in the center regions of higher slip (Carlos Mendoza and Hartzell, 1988;

398 Dietz and Ellsworth, 1990; Wetzler et al., 2018). This is because most of the strain in the regions 
of higher slip are already released during the mainshock and hence these areas are less able to 400 generate aftershocks. We test this hypothesis using a slightly modified version of the method used

401 in Wetzler et al. (2018), which calculates the distances of aftershocks from the slip contours of 402 several earthquakes and normalizes by the radius of a circle that has an area equal to the area 403 enclosed by the slip contour. As many of our slip contours are elongated, we change the 404 normalization constant to the minor axis of an ellipse fitted to the slip contours (Wijewickrema and Paplínski, 2004), as shown in Figure 10. The distances are then calculated from the closest slip contour (if there are multiple parts) and normalized by the minor axis of the ellipse fitted to

407 that slip contour. Negative distances refer to distances of aftershocks inside the slip contour while 408 positive distances refer to distances of aftershocks outside the slip contour. We use this method to analyze one slip model from each earthquake (list of models in Table S9). We find that most of

410 the aftershocks are located near the slip contours, within a distance of -0.25 to 0.25 the slip 411 contours. Compared to the results obtained by Wetzler et al. (2018), we find more earthquakes 412 located between 0.5 to 1 distance inside the slip contours (Figure 11), probably because we use the 413 minor axis of an ellipse as the normalization constant. But our results still support the notion that 414 there is a deficit of earthquakes in the central regions of the largest slip.

\section{Conclusion}

416 We have developed a consistent method to quantify aftershock zone and mainshock rupture areas, 417 and analyzed 12 mainshocks $(\mathrm{Mw} \geq 5.4)$ in California. We find that the ratios of aftershock zone 418 areas to mainshock rupture areas lie within a range of 0.5 to 5.4 , and can be used as a first order 419 estimate of the mainshock rupture area, especially for early aftershock durations where ratios range 420 from 0.5 to 3.5. Using either the relocated catalog or the ANSS catalog leads to similar patterns of 421 the aftershock zone area. Our results show that Coulomb stress change exhibits a positive correlation with aftershock zone area, suggesting that the mainshock slip contributes to aftershock 
423 distribution. Moreover, a combination of different mechanisms should be used to better explain

424 the aftershock zone areas (especially for the entire aftershock duration) for several mainshocks.

425 Further studies should be directed towards understanding how the relationship between the 426 aftershock zone area and the mainshock rupture area varies for earthquakes in different tectonic 427 environments and crustal structures.

\section{Data and Resources}

429 Slip inversion data was downloaded from the SRCMOD website at http://equake-rc.info (last 430 accessed July 2020). Earthquake catalogs were obtained from the NCEDC www.ncedc.org (last 431 accessed October 2019) and SCEDC websites http://scedc.caltech.edu (last accessed October 432 2019) and the catalog by Dr. Felix Waldhauser, 433 https://www.ldeo.columbia.edu/ felixw/NCAeqDD/ (last accessed March 2019), version 434 NCAeqDD.v201112.1. Earthquakes from the ANSS ComCat Catalog were downloaded from 435 USGS https://earthquake.usgs.gov/earthquakes/search/ (last accessed August 2019) and Coulomb 4363 MATLAB codes were downloaded from the USGS website,

437 https://earthquake.usgs.gov/research/software/coulomb/ (last accessed July 2019). We obtained 438 MATLAB codes written by D. Schorlemmer and J. Woessner to calculate Mc from 439 geophysics.eas.gatech.edu/people/bsullivan/tutorial/StatisticalSeismology.htm (last accessed 440 March 2019). The supplementary material contains additional information about individual 441 earthquakes, early aftershock ratios and the results of Coulomb stress change calculations.

442 Acknowledgements

443 We thank two anonymous reviewers and editors Martin C. Chapman and Thomas Pratt for their 444 insightful feedback for this paper. We also thank the CN Yang Scholars Program, Nanyang 445 Technological University, and the University of Michigan for supporting the undergraduate 446 research study of Jing Ci Neo. We would also like to express appreciation to Carissa Tan Xiwen 
National Science Foundation through grant award 1943742.

\section{References}

Aron, A., and J. L. Hardebeck, 2009, Seismicity rate changes along the central California coast due to stress changes from the 2003 M 6.5 San Simeon and 2004 M 6.0 Parkfield earthquakes, Bull. Seismol. Soc. Am., doi: $10.1785 / 0120080239$.

Behr, J., R. Bilham, P. Bodin, R. O. Burfoid, and R. Bürgmann, 1990, Aseismic slip on the San Andreas Fault south of Loma Prieta, Geophys. Res. Lett., doi: 10.1029/GL017i009p01445.

Belardinelli, M. E., A. Bizzarri, and M. Cocco, 2003, Earthquake triggering by static and dynamic stress changes, J. Geophys. Res. Solid Earth, 108, no. B3, 2135, doi: 10.1029/2002jb001779.

Bennett, R. A., R. E. Reilinger, W. Rodi, Y. P. Li, M. N. Toksoz, and K. Hudnut, 1995, Coseismic Fault Slip Associated with the 1992 M(W)-6.1 Joshua-Tree, California, Earthquake - Implications for the JoshuaTree Landers Earthquake Sequence, J. Geophys. Res., 100, no. B4, 6443-6461

Bouchon, M., V. Durand, D. Marsan, H. Karabulut, and J. Schmittbuhl, 2013, The long precursory phase of most large interplate earthquakes, Nat. Geosci., 6, 299-302, doi: 10.1038/ngeo1770.

Bürgmann, R., P. Segall, M. Lisowski, and J. L. Svarc, 1997, Postseismic strain following the Loma Prieta earthquake from repeated GPS measurements, J. Geophys. Res., 102, no. B3, 4933-4955.

Cattania, C., S. Hainzl, L. Wang, B. Enescu, and F. Roth, 2015, Journal of Geophysical Research : Solid Earth Aftershock triggering by postseismic stresses : A study based on Coulomb rate-and-state models, J. Geophys. Res. Solid Earth, 120, 2388-2407, doi: 10.1002/2014JB011500.The.

Chapman, M. C., 2013, On the Rupture Process of the 23 August 2011 Virginia Earthquake, Bull. Seism. Soc. Am, 103, no. 2A, 613-628.

Cotton, F., and M. Campillo, 1995, Frequency-Domain Inversion of Strong Motions - Application to the 1992 Landers Earthquake, J. Geophys. Res., 100, no. B3, 3961-63975.

Custodio, S., P. C. Liu, and R. J. Archuleta, 2005, The 2004 Mw 6.0 Parkfield, California, earthquake: Inversion of near-source ground motion using multiple data sets, Geophys. Res. Lett., 32, no. L23312.

Das, S., and C. Henry, 2003, Spatial relation between main earthquake slip and its aftershock distribution, Rev. Geophys., 41, no. 3.

Diao, F., X. Xiong, R. Wang, Y. Zheng, T. R. Walter, H. Weng, and J. Li, 2014, Overlapping post-seismic deformation processes: Afterslip and viscoelastic relaxation following the 2011Mw 9.0 tohoku (Japan) earthquake, Geophys. J. Int., 196, 218-229, doi: 10.1093/gji/ggt376.

Dietz, L. D., and W. L. Ellsworth, 1990, The October 17, 1989, Loma Prieta, California, Earthquake and its aftershocks: Geometry of the sequence from high-resolution locations, Geophys. Res. Lett., doi: 10.1029/GL017i009p01417.

Dodge, D. A., G. C. Beroza, and W. L. Ellsworth, 1995, Foreshock sequence of the 1992 Landers, California, earthquake and its implications for earthquake nucleation, J. Geophys. Res., 100, no. B7, 9865-9880, doi: 10.1029/95JB00871.

Dreger, D. S., L. Gee, P. Lombard, M. H. Murray, and B. Romanowicz, 2005, Rapid finite-source analysis and nearfault strong ground motions: Application to the 2003 M-w 6.5 San Simeon and 2004 Mw 6.0 Parkfield earthquakes, Seismol. Res. Lett., 76, no. 1, 40-48.

Ebel, J. E., and D. W. Chambers, 2016, Using the locations of $M \geq 4$ earthquakes to delineate the extents of the ruptures of past major earthquakes, Geophys. J. Int., 2, no. 1, 862-875 doi: 10.1093/gji/ggw312.

Emolo, A., and A. Zollo, 2005, Kinematic Source Parameters for the 1989 Loma Prieta Earthquake from the Nonlinear Inversion of Accelerograms, Bull. Seism. Soc. Am, 95, no. 3, 981-994.

Fan, W., and P. M. Shearer, 2016, Local near instantaneously dynamically triggered aftershocks of large earthquakes, Geophysics, 353, no. 6304, 1133-1136.

Fialko, Y., 2006, Interseismic strain accumulation and the earthquake potential on the southern San Andreas fault system, Nature, 441, 968-971, doi: 10.1038/nature04797.

Freed, A. M., 2005, Earthquake triggering by static, dynamic, and postseismic stress transfer, Annu. Rev. Earth Planet. Sci., 33, no. October 1999, 335-367, doi: 10.1146/annurev.earth.33.092203.122505.

Gallovič, F., 2016, Modeling velocity recordings of the mw 6.0 south napa, California, earthquake: Unilateral event with weak high-frequency directivity, Seismol. Res. Lett., 87, no. 1, 2-14, doi: 10.1785/0220150042.

Hardebeck, J. L., J. J. Nazareth, and E. Hauksson, 1998, The static stress change triggering model: Constraints from two southern California aftershock sequences, J. Geophys. Res., 103, no. B10, 24,427-24,437. 
Hartzell, S., 1989, Comparison of Seismic Waveform Inversion Results for the Rupture History of a Finite Fault Application to the 1986 North Palm-Springs, California, Earthquake, J. Geophys. Res., 94, no. B6, 75157534.

Hartzell, S. H., and M. Iida, 1990, Source complexity of the 1987 Whittier Narrows, California, earthquake from the inversion of strong motion records, J. Geophys. Res., 95, no. 8, 12,475-12,485.

Hauksson, E., L. M. Jones, and K. Hutton, 2002, The 1999 Mw 7.1 Hector Mine, California, earthquake sequence: Complex conjugate strike-slip faulting, Bull. Seismol. Soc. Am., 92, no. 4, 1154-1170, doi: $10.1785 / 0120000920$.

Hauksson, E., W. Yang, and P. M. Shearer, 2012, Waveform relocated earthquake catalog for Southern California (1981 to June 2011), Bull. Seismol. Soc. Am., 102, no. 5, 2239-2244, doi: 10.1785/0120120010.

Hernandez, B., F. Cotton, and M. Campillo, 1999, Contribution of radar interferometry to a two-step inversion of the kinematic process of the 1992 Landers earthquake, J. Geophys. Res., 104, no. B6, 13083-13099.

Ji, C., 2004, Slip history the 2004 (Mw 5.9) Parkfield Earthquake (Single-Plane Model), Caltech: $<$ http://www.tectonics.caltech.edu/slip_history/2004_ca/parkfield2.html> (accessed Mar 26, 2019).

Johnson, C. W., and R. Bürgmann, 2016, Delayed dynamic triggering: Local seismicity leading up to three remote $M \geq 6$ aftershocks of the 11 April 2012 M8.6 Indian Ocean earthquake, J. Geophys. Res. Solid Earth, 121, 134-151, doi: 10.1002/2015JB012608.Received.

Jonsson, S., H. Zebker, P. Segall, and F. Amelung, 2002, Fault slip distribution of the 1999 Mw 7.1 Hector Mine, California, earthquake, estimated from satellite radar and GPS measurements, Bull. Seis. Soc. Am, 92, no. 4, 1377-1389.

Kanamori, H., 1977, The energy release in great earthquakes, J. Geophys. Res., 82, no. 20, 2981-2987, doi: 10.1029/jb082i020p02981.

Kaverina, A., D. Dreger, and E. Price, 2002, The combined inversion of seismic and geodetic data for the source process of the 16 October 1999 Mw 7.1 Hector Mine, California, earthquake, Bull. Seism. Soc. Am, 92, no. 4, 1266-1280.

Khoshmanesh, M., and M. Shirzaei, 2018, Episodic creep events on the San Andreas Fault caused by pore pressure variations, Nat. Geosci., 11, no. 8, 610-614, doi: 10.1038/s41561-018-0160-2.

Kilb, D., J. Gomberg, and P. Bodin, 2002, Aftershock triggering by complete Coulomb stress changes, J. Geophys. Res. Solid Earth, 107, no. B4, 2060, doi: 10.1029/2001jb000202.

Kilb, D., J. Gomberg, and P. Bodin, 2000, Triggering of earthquake aftershocks by dynamic stresses, Nature, 408, $570-574$.

King, G. C. P., R. S. Stein, and Jian Lin, 1994, Static stress changes and the triggering of earthquakes, Bull. Seismol. Soc. Am., 84, no. 3, 935-953, doi: 10.1016/0148-9062(95)94484-2.

Knopoff, L., Y. Y. Kagan, and R. Knopoff, 1982, b Values for Foreshocks and Aftershocks in Real and Simulated Earthquake Sequences, Bull. Seismol. Soc. Am., 72, no. 5, 1663-1676.

Larsen, S., R. Reilinger, H. Neugebauer, and W. Strange, 1992, Global Positioning System Measurements of Deformations Associated with the 1987 Superstition Hills Earthquake - Evidence for Conjugate Faulting, J. Geophys. Res., 97, no. B4, 4885-4902.

Marsan, D., and O. Lengliné, 2010, A new estimation of the decay of aftershock density with distance to the mainshock, J. Geophys. Res. Solid Earth, 115, no. B09302, doi: 10.1029/2009JB007119.

Matthews, M. V., and P. A. Reasenberg, 1988, Statistical methods for investigating quiescence and other temporal seismicity patterns, Pure Appl. Geophys., 126, nos. 2-4, 357-372, doi: 10.1007/BF00879003.

Meade, B. J., P. M. R. DeVries, J. Faller, F. Viegas, and M. Wattenberg, 2017, What Is Better Than Coulomb Failure Stress? A Ranking of Scalar Static Stress Triggering Mechanisms from 105 Mainshock-Aftershock Pairs, Geophys. Res. Lett., doi: 10.1002/2017GL075875.

Mendoza, C., and S. H. Hartzell, 1988, Aftershock patterns and main shock faulting, Bull. Seismol. Soc. Am., 78, no. $4,1438-1449$.

Mendoza, Carlos, and S. H. Hartzell, 1988, Inversion for Slip Distribution Using Teleseismic P Waveforms: North Palm Springs, Borah Peak and Michocan Earthquakes, Bull. Seismol. Soc. Am., 78, no. 3, 1092-1111.

Meng, X., and Z. Peng, 2016, Increasing lengths of aftershock zones with depths of moderate-size earthquakes on the San Jacinto Fault suggests triggering of deep creep in the middle crust, Geophys. J. Int., doi: $10.1093 / \mathrm{gji} / \mathrm{ggv} 445$.

Meng, X., Z. Peng, C. Aiken, and D. Kilb, 2014, Dynamically Triggered Earthquakes in the Geysers Region following the 2014 M6.0 South Napa Earthquake, Eos AGU Fall Meet.

Mignan, A., and J. Woessner, 2012, Estimating the magnitude of completeness for earthquake catalogs, Community Online Resource for Statistical Seismicity Analysis, Community Online Resour. Stat. Seism. Anal., doi: 10.5078/corssa-00180805.

Moore, D. E., and M. J. Rymer, 2007, Talc-bearing serpentinite and the creeping section of the San Andreas fault, Nature, 448, 795-797, doi: 10.1038/nature06064.

Oppenheimer, D. H., 1990, Aftershock Slip Behavior of the 1989 Loma California Earthquake, Geophys. Res. Lett., 
Parsons, T., 2002, Global Omori law decay of triggered earthquakes: Large aftershocks outside the classical aftershock zone, J. Geophys. Res. Solid Earth, 107, no. B9, 2199, doi: 10.1029/2001jb000646.

Parsons, T., and E. L. Geist, 2014, The 2010-2014.3 global earthquake rate increase, Geophys. Res. Lett., 41, 44794485, doi: 10.1002/2014GL061184.Received.

Perfettini, H., and J. P. Avouac, 2007, Modeling aftership and aftershocks following the 1992 Landers earthquake, J. Geophys. Res. Solid Earth, doi: 10.1029/2006JB004399.

Perfettini, H., and J.-P. Avouac, 2004, Postseismic relaxation driven by brittle creep: A possible mechanism to reconcile geodetic measurements and the decay rate of aftershocks, application to the Chi-Chi earthquake, Taiwan, J. Geophys. Res. Solid Earth, 109, no. B02304, doi: 10.1029/2003jb002488.

Perfettini, H., W. B. Frank, D. Marsan, and M. Bouchon, 2018, A Model of Aftershock Migration Driven by Afterslip, Geophys. Res. Lett., 45, 2283-2293, doi: 10.1002/2017GL076287.

Pollitz, F. F., R. Bürgmann, and P. Segall, 1998, Joint estimation of afterslip rate and postseismic relaxation following the 1989 Loma Prieta earthquake, J. Geophys. Res. Solid Earth, 103, no. B11, 26,975-26,992, doi: 10.1029/98jb01554.

Ross, Z. E., D. T. Trugman, E. Hauksson, and P. M. Shearer, 2019, Searching for hidden earthquakes in Southern California, Science (80-. )., 364, 767-771, doi: 10.1126/science.aaw6888.

Savage, J. C., J. L. Svarc, and S. B. Yu, 2007, Postseismic relaxation and aftershocks, J. Geophys. Res. Solid Earth, 112, no. B06406, doi: 10.1029/2006JB004584.

Stein, R. S., A. A. Barka, and J. H. Dieterich, 1997, Progressive failure on the North Anatolian fault since 1939 by earthquake stress triggering, Geophys. J. Int., 127, 594-604.

Sykes, L. R., 1971, Aftershock zones of great earthquakes, seismicity gaps, and earthquake prediction for Alaska and the Aleutians, J. Geophys. Res., 76, no. 32, 8021-8041, doi: 10.1029/jb076i032p08021.

Tajima, F., and H. Kanamori, 1985, Global survey of aftershock area expansion patterns, Phys. Earth Planet. Inter., doi: 10.1016/0031-9201(85)90066-4.

Toda, S., R. S. Stein, and J. Lin, 2011, Widespread seismicity excitation throughout central Japan following the $2011 \mathrm{M}=9.0$ Tohoku earthquake and its interpretation by Coulomb stress transfer, Geophys. Res. Lett., 38 , no. L00G03, doi: 10.1029/2011GL047834.

Toda, S., R. S. Stein, P. a Reasenberg, and H. Dieterich, 1998, Stress transferred by the $1995 \mathrm{Mw}=6.9$ Kobe, Japan, shock: Effect on aftershocks and future earthquake probabilities, J. Geophys. Res., 103, no. B10, 24,543-24, 565.

Utsu, T., 1969, Instructions for use Aftershocks and Earthquake Statistics (I), J. Fac. Sci. Hokkaido Univ., 3, no. 3, 129-195.

Van Der Elst, N. J., and E. E. Brodsky, 2010, Connecting near-field and far-field earthquake triggering to dynamic strain, J. Geophys. Res., 115, no. B07311, doi: 10.1029/2009JB006681.

Wald, D. J., D. V. Helmberger, and T. H. Heaton, 1991, Rupture Model of the 1989 Loma-Prieta Earthquake from the Inversion of Strong-Motion and Broad-Band Teleseismic Data, Bull. Seism. Soc. Am, 81, no. 5, 15401572 .

Wald, D. J., T. H. Heaton, and K. W. Hudnut, 1996, The slip history of the 1994 Northridge, California, earthquake determined from strong-motion, teleseismic, GPS, and leveling data, Bull. Seism. Soc. Am, 86, 1B, S49S70.

Waldhauser, F., 2009, Near-real-time double-difference event location using long-term seismic archives, with application to northern California, Bull. Seismol. Soc. Am., 99, no. 5, 2736-2748, doi: 10.1785/0120080294.

Waldhauser, F., and D. P. Schaff, 2008, Large-scale relocation of two decades of Northern California seismicity using cross-correlation and double-difference methods, J. Geophys. Res. Solid Earth, 113, no. B08311, doi: 10.1029/2007JB005479.

Wei, S., D. V. Helmberger, S. Owen, R. W. Graves, K. W. Hudnut, and E. Fielding, 2013, Complementary slip distributions of the largest earthquakes in the 2012 Brawley swarm, Imperial Valley, California. Geophys. Res. Lett., 40, 847-852, doi:10.1002/grl.50259.

Wei, S., E. Fielding, S. Leprince, A. Sladen, J. P. Avouac, D. Helmberger, E. Hauksson, R. Chu, M. Simons, K. Hudnut, T. Herring, and R. Briggs, 2011, Superficial simplicity of the 2010 El Mayor-Cucapah earthquake of Baja California in Mexico, Nat. Geosci., 4, 615-618, doi:10.1038/ngeo1213.

Wei, S., S. Barbot, R. Graves, J. J. Lienkaemper, T. Wang, K. Hudnut, Y. Fu, and D. Helmberger, 2015, The 2014 Mw 6.1 South Napa Earthquake: A unilateral rupture with shallow asperity and rapid afterslip, Seismol. Res. Lett., 86, no. 2A, 344-354, doi: 10.1785/0220140249.

Wetzler, N., T. Lay, E. E. Brodsky, and H. Kanamori, 2018, Systematic deficiency of aftershocks in areas of high coseismic slip for large subduction zone earthquakes, Sci. Adv., doi: 10.1126/sciadv.aao3225.

Wijewickrema, S. N. R., and A. P. Paplínski, 2004, Principal Component Analysis for the Approximation of a Fruit as an Ellipse.

Wu, Q., and M. C. Chapman, 2017, Stress-Drop Estimates and Source Scaling of the 2011 Mineral, Virginia, 
Mainshock and Aftershocks, Bull. Seism. Soc. Am, 107, no. 6, 2703-2720. Earthquake: Temporal and Spatial Distribution, Focal Mechanisms, Regional Stress, and the Role of Coulomb Stress Transfer, Bull. Seism. Soc. Am, 105, no. 5, 2521-2537.

Zeng, Y., and J. Anderson, 2000, Evaluation of numerical procedures for simulating near-fault long-period ground motions using Zeng method, Report 2000/01 to the PEER Utilities Program, Berkeley: $<$ http://peer.berkeley.edu> (accessed March 23, 2019).

631 
632 Full Mailing Addresses of Authors

633

634 Jing $\mathrm{Ci}$ Neo

635 University of Michigan, Ann Arbor. Room 4534F, 1100 North University

636

637 Yihe Huang

638 University of Michigan, Ann Arbor. Room 4534F, 1100 North University

639

640 Dongdong Yao

641 University of Michigan, Ann Arbor. Room 4534F, 1100 North University

642

643 Shengji Wei

644 Earth Observatory of Singapore, 50 Nanyang Avenue, Block N2-01a-15

645

646 
Figure 1. Map of mainshock locations in this study. Known faults are specified as dark red lines, and the direction of plate motion is indicated by black arrows.

Figure 2. Illustration of how the aftershock zone area of each mainshock is defined using the $\beta$ values. The diagrams show the fault plane view, with $\beta$ values of each grid cell calculated from the aftershocks projected on to the fault plane. Aftershocks from the relocated catalogs are used for this figure.

Figure 3. Illustration of how aftershock duration is calculated. The horizontal black line is at a $\beta$ value of 2 , and the aftershock duration is taken to be the end of the time window where the $\beta$ value first dips below the line (indicated by the stars). If the $\beta$ value never dips below 2,1 year is used. For example, the aftershock durations for Parkfield and Northridge are the same ( $>1$ year).

Figure 4. Depiction of how the Coulomb stress change area is calculated. For illustration, a contour is drawn around the boundary of cells with a positive Coulomb stress change of $>1 \mathrm{MPa}$ or more. The Coulomb stress change area is given by the sum of the area of these cells.

Figure 5. Plot of the data types used for each slip inversion, where the ratios are calculated using the relocated catalogs. SGM: Strong ground motion; Teleseismic: Teleseismic waveform data; Geodetic: GPS, INSAR.

Figure 6. Aftershock zone area ratios for different earthquakes using different earthquake catalogs. If there are multiple slip inversions for the same earthquake, the ratios are slightly offset so that they do not overlap. The error bars are calculated using slip contours of 0.1 and 0.2 of the maximum slip to calculate different rupture areas. (Top) NCEDC data is used to calculate the aftershock zone area for the first 3 earthquakes, while SCEDC data is used for the rest of the earthquakes. (Bottom) ANSS catalog is used. The ratio for the Whittier Narrows (WN) earthquake is not obtained from the ANSS catalog because the data does not yield a robust estimation of the magnitude of completeness.

Figure 7. Aftershock ratios calculated from 1-day aftershock durations for both earthquake catalogs. The aftershock ratios for the whole duration is plotted in the background in light grey for comparison.

Figure 8. Aftershock zone area vs. Coulomb stress change area.

Figure 9. Robust fitting (solid line) and least squares fitting (dashed line) of ratios of Coulomb stress area to aftershock zone area with magnitude.

Figure 10. Illustration of how the distances from slip contour are calculated using the Parkfield, Chen Ji et al slip model.

Figure 11. Histogram of aftershock distances from slip contours for all earthquakes using the relocated and ANSS catalogs. 


\section{List of Tables}

\section{Table 1}

Summary of the source properties and ratios of earthquakes.

\begin{tabular}{|c|c|c|c|c|c|c|c|c|}
\hline Earthquake & Date & $\begin{array}{l}\text { Location } \\
\text { N/W }\end{array}$ & $\begin{array}{c}\text { Magnitude } \\
\text { (Mw) }\end{array}$ & $\begin{array}{l}\text { Depth } \\
(\mathbf{k m})\end{array}$ & Slip Inversion References & Data Sources* & Reloc. & ANSS \\
\hline \multirow{2}{*}{$\begin{array}{l}\text { South Napa } \\
\text { (SN) }\end{array}$} & \multirow{2}{*}{$2014 / 08 / 24$} & \multirow{2}{*}{$38.22 / 122.31$} & 6.10 & 11.0 & Wei et al (2015) & SGM & 1.04 & 0.92 \\
\hline & & & 6.07 & 10.0 & Gallovič (2016) & SGM & 4.16 & 3.66 \\
\hline \multirow{3}{*}{ Parkfield (Pf) } & \multirow{3}{*}{$2004 / 09 / 28$} & \multirow{3}{*}{$35.82 / 120.37$} & 5.90 & 8.0 & $\mathrm{Ji}(2004)$ & SGM, GPS & 1.28 & 2.04 \\
\hline & & & 6.00 & 8.3 & Dreger et al (2005) & SGM, GPS & 2.37 & 2.70 \\
\hline & & & 6.06 & 8.3 & Custodio et al (2005) & SGM & 2.36 & 2.18 \\
\hline \multirow{4}{*}{$\begin{array}{l}\text { Loma Prieta } \\
\text { (LP) }\end{array}$} & \multirow{4}{*}{$1989 / 10 / 18$} & \multirow{4}{*}{$37.04 / 121.88$} & 6.98 & 17.6 & Zeng and Anderson (2000) & SGM & 5.38 & 4.54 \\
\hline & & & 6.94 & 17.6 & Wald et al (1991) & SGM, TELE & 4.19 & 3.53 \\
\hline & & & 6.96 & 17.6 & Beroza (1991) & SGM & 3.82 & 5.23 \\
\hline & & & 6.91 & 17.6 & Emolo and Zollo (2005) & SGM & 3.40 & 4.69 \\
\hline $\begin{array}{l}\text { Brawley } \\
\text { Swarm (BS) }\end{array}$ & $2012 / 08 / 26$ & $33.02 / 115.54$ & 5.45 & 6.4 & Wei et al (2013) & SGM, GPS & 0.82 & 2.29 \\
\hline \multirow{2}{*}{$\begin{array}{l}\text { El-Mayor- } \\
\text { Cucapah } \\
(\text { EMC) }\end{array}$} & \multirow[b]{2}{*}{$2010 / 04 / 04$} & \multirow[b]{2}{*}{$32.30 / 115.30$} & 7.35 & 10.0 & Mendoza and Hartzell (2013) & TELE & 2.17 & 2.61 \\
\hline & & & 7.29 & 5.5 & Wei et al (2011) & $\begin{array}{c}\text { TELE, SPOT, } \\
\text { GPS, INSAR, SAR }\end{array}$ & 1.79 & 1.74 \\
\hline \multirow{2}{*}{$\begin{array}{l}\text { Hector Mine } \\
(\mathrm{HM})\end{array}$} & \multirow{2}{*}{$1999 / 10 / 16$} & \multirow{2}{*}{$34.59 / 116.27$} & 7.24 & 6.0 & Kaverina et al (2002) & SGM, GPS & 1.26 & 1.18 \\
\hline & & & 7.16 & 15.0 & Jonsson et al (2002) & GPS, INSAR & 1.49 & 0.98 \\
\hline \multirow{4}{*}{$\begin{array}{l}\text { Northridge } \\
(\mathrm{Nr})\end{array}$} & \multirow{4}{*}{$1994 / 01 / 17$} & \multirow{4}{*}{$34.21 / 118.54$} & 6.71 & 17.5 & Zeng and Anderson (2000) & SGM & 2.33 & 3.01 \\
\hline & & & 6.80 & 17.5 & Wald et al (1996) & SGM, TELE, GPS & 1.30 & 1.88 \\
\hline & & & 6.81 & 17.5 & Hudnut et al (1996) & TRIL, GPS & 1.38 & 1.67 \\
\hline & & & 6.73 & 17.5 & Hartzell et al (1996) & SGM & 1.21 & 1.49 \\
\hline \multirow{3}{*}{ Landers (Ld) } & \multirow{3}{*}{$1992 / 06 / 28$} & \multirow{3}{*}{$34.20 / 116.43$} & 7.20 & 7.0 & Zeng and Anderson (2000) & SGM & 1.18 & 0.88 \\
\hline & & & 7.22 & 7.0 & Hernandez et al (1999) & SGM, GPS & 1.80 & 1.26 \\
\hline & & & 7.29 & 7.0 & Cotton and Campillo (1995) & SGM & 1.47 & 1.15 \\
\hline Joshua Tree (JT) & $1992 / 04 / 23$ & $34.00 / 116.32$ & 6.25 & 12.5 & Bennett et al (1995) & TRIL, GPS & 2.12 & 1.96 \\
\hline $\begin{array}{l}\text { Elmore Ranch } \\
(\mathrm{ER})\end{array}$ & $1987 / 11 / 24$ & $33.08 / 115.80$ & 6.52 & 10.0 & Larsen et al (1992) & TRIL, GPS & 4.30 & 2.06 \\
\hline $\begin{array}{l}\text { Whittier Narrows } \\
(\mathrm{WN})\end{array}$ & $1987 / 10 / 01$ & $34.05 / 118.08$ & 5.89 & 14.6 & Hartzell and Iida (1990) & SGM & 1.61 & NA \\
\hline \multirow{2}{*}{$\begin{array}{l}\text { North Palm } \\
\text { Springs (NPS) }\end{array}$} & \multirow{2}{*}{ 1986/07/08 } & \multirow{2}{*}{$34.00 / 116.57$} & 6.14 & 11.0 & Hartzell (1989) & SGM & 0.54 & 0.79 \\
\hline & & & 6.21 & 11.0 & Mendoza and Hartzell (1988) & TELE & 1.87 & 2.72 \\
\hline
\end{tabular}

*SGM: Strong ground motion, TELE: Teleseismic data, GPS: Global Positioning System, SAR: Synthetic-

697 Aperture Radar, INSAR: Interferometric Synthetic-Aperture Radar, SPOT: Optical imaging from the

698 SPOT-5 satellite. 
702

703

704

705

\begin{tabular}{lcccc}
\hline & \multicolumn{2}{c}{ Entire Duration } & \multicolumn{2}{c}{ 1-Day Aftershocks } \\
& Reloc. Catalogs & ANSS Catalog & Reloc. Catalogs & ANSS Catalog \\
\hline Mean & 2.18 & 2.16 & 1.83 & 1.70 \\
Variance & 1.58 & 1.90 & 0.84 & 1.07 \\
Median & 1.80 & 2.00 & 1.71 & 1.75 \\
Mean Absolute Deviation & 0.98 & 1.03 & 0.77 & 0.84
\end{tabular}

Table 2

Statistics of the ratios

706

707

708 
709

710

711

712 


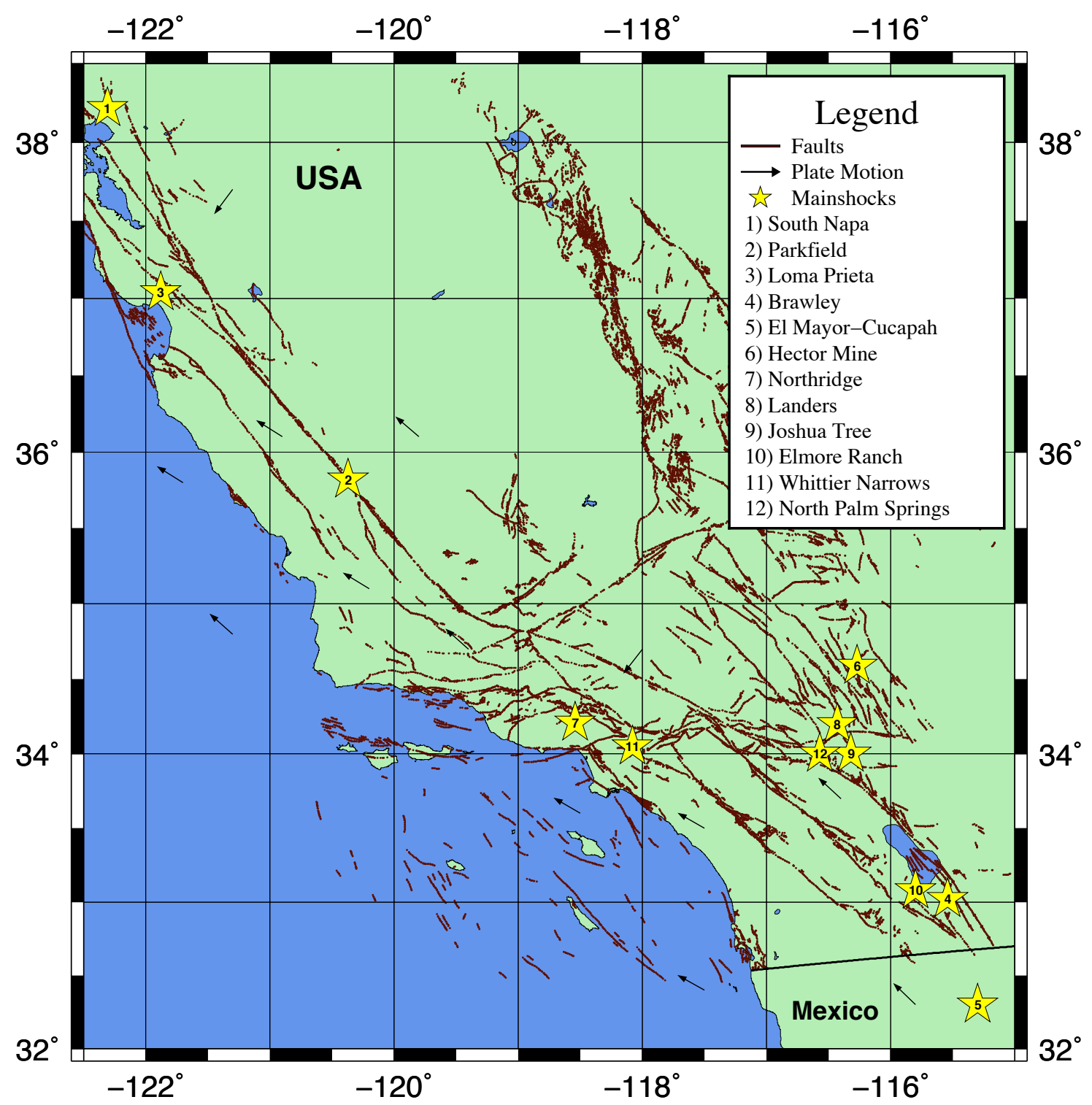

715 Figure 1. Map of mainshock locations in this study. Known faults are specified as dark red lines, and the 716 direction of plate motion is indicated by black arrows. 

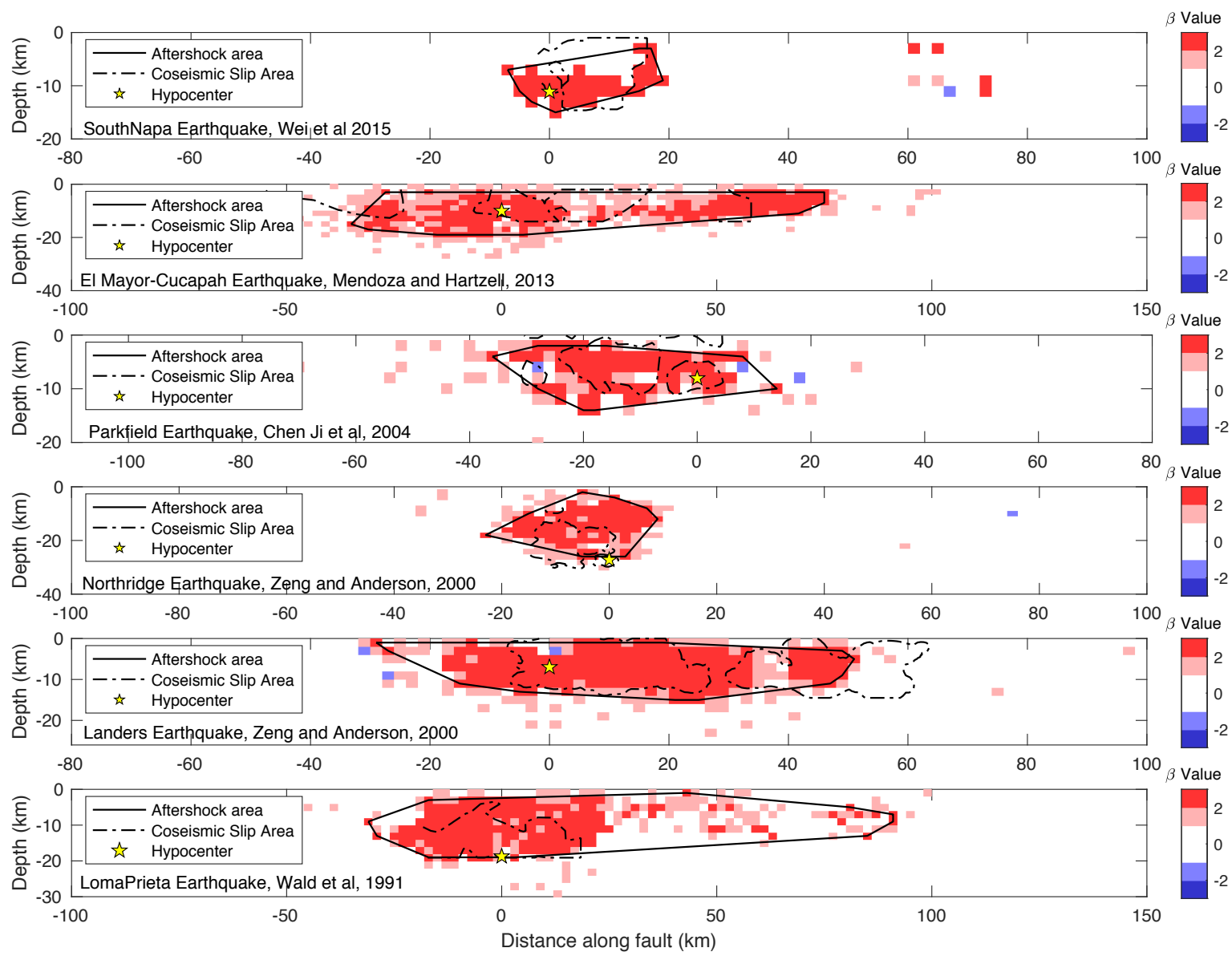

Distance along fault (km)

718 Figure 2. Illustration of how the aftershock zone area of each mainshock is defined using the $\beta$ values. The 719 diagrams show the fault plane view, with $\beta$ values of each grid cell calculated from the aftershocks 720 projected on to the fault plane. Aftershocks from the relocated catalogs are used for this figure.

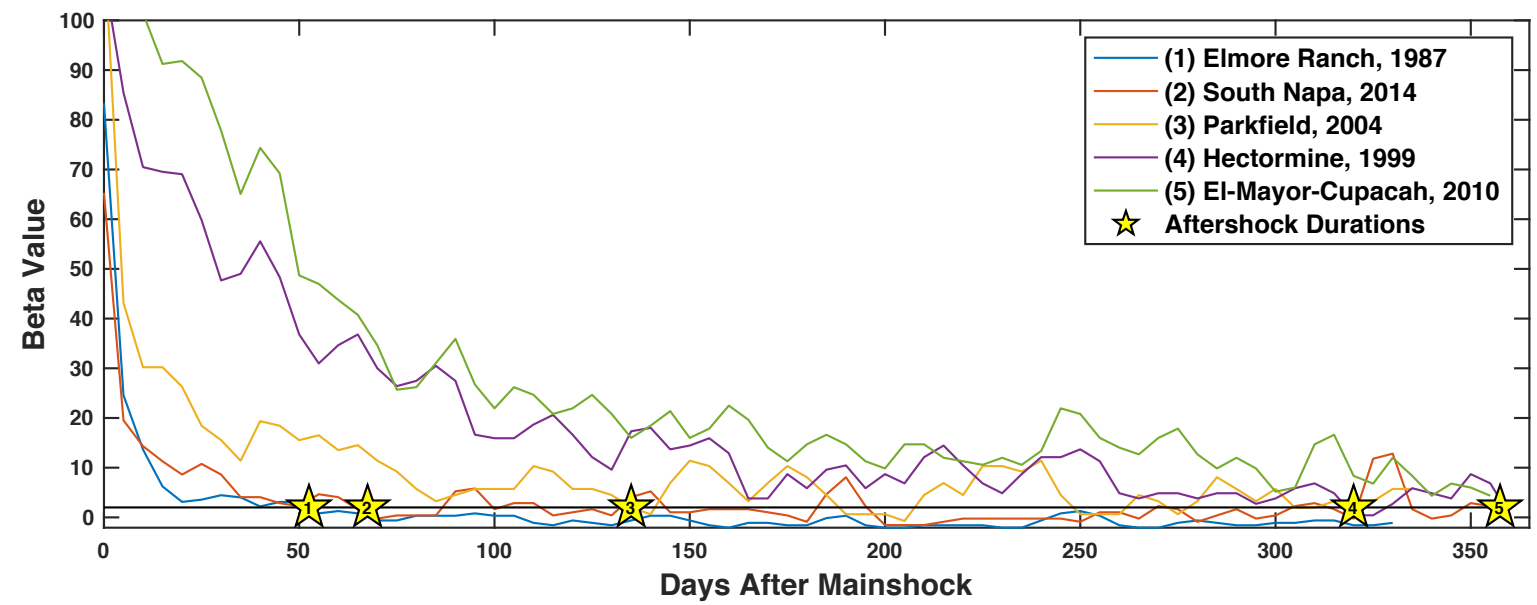

Days After Mainshock

723 Figure 3. Illustration of how aftershock duration is calculated. The horizontal black line is at a $\beta$ value of 7242 , and the aftershock duration is taken to be the end of the time window where the $\beta$ value first dips below 725 the line (indicated by the numbered stars). If the $\beta$ value never dips below 2,1 year is used. 


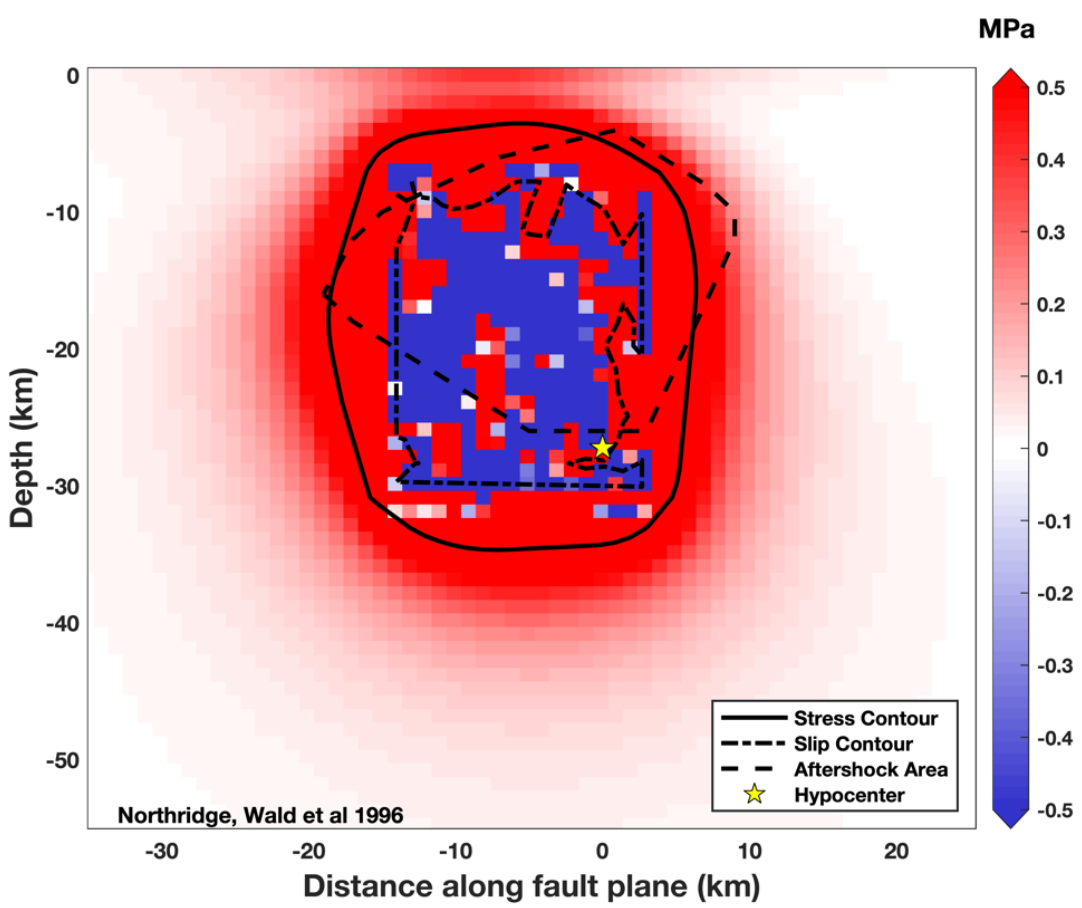

Figure 4. Depiction of how the Coulomb stress change area is calculated. For illustration, a contour is drawn around the boundary of cells with a positive Coulomb stress change of $>1 \mathrm{MPa}$ or more. The Coulomb stress change area is given by the sum of the area of these cells.

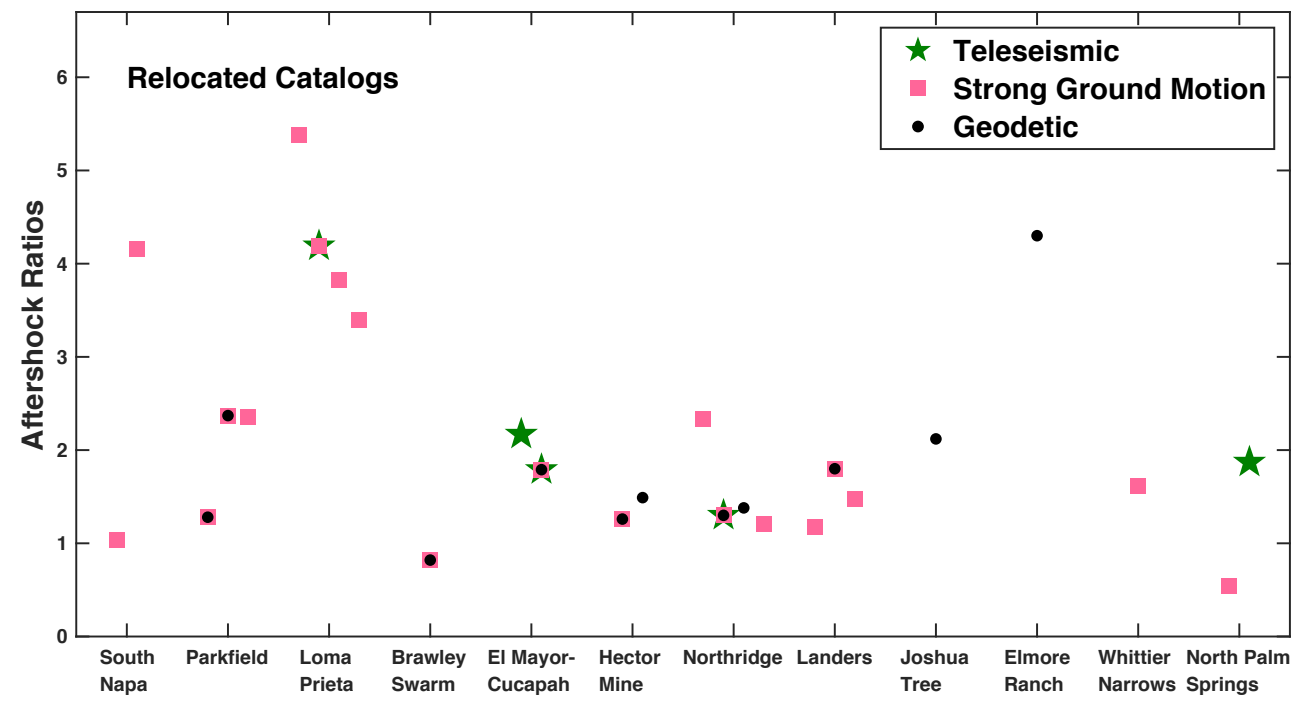

Figure 5. Plot of the data types used for each slip inversion, where the ratios are calculated using the 

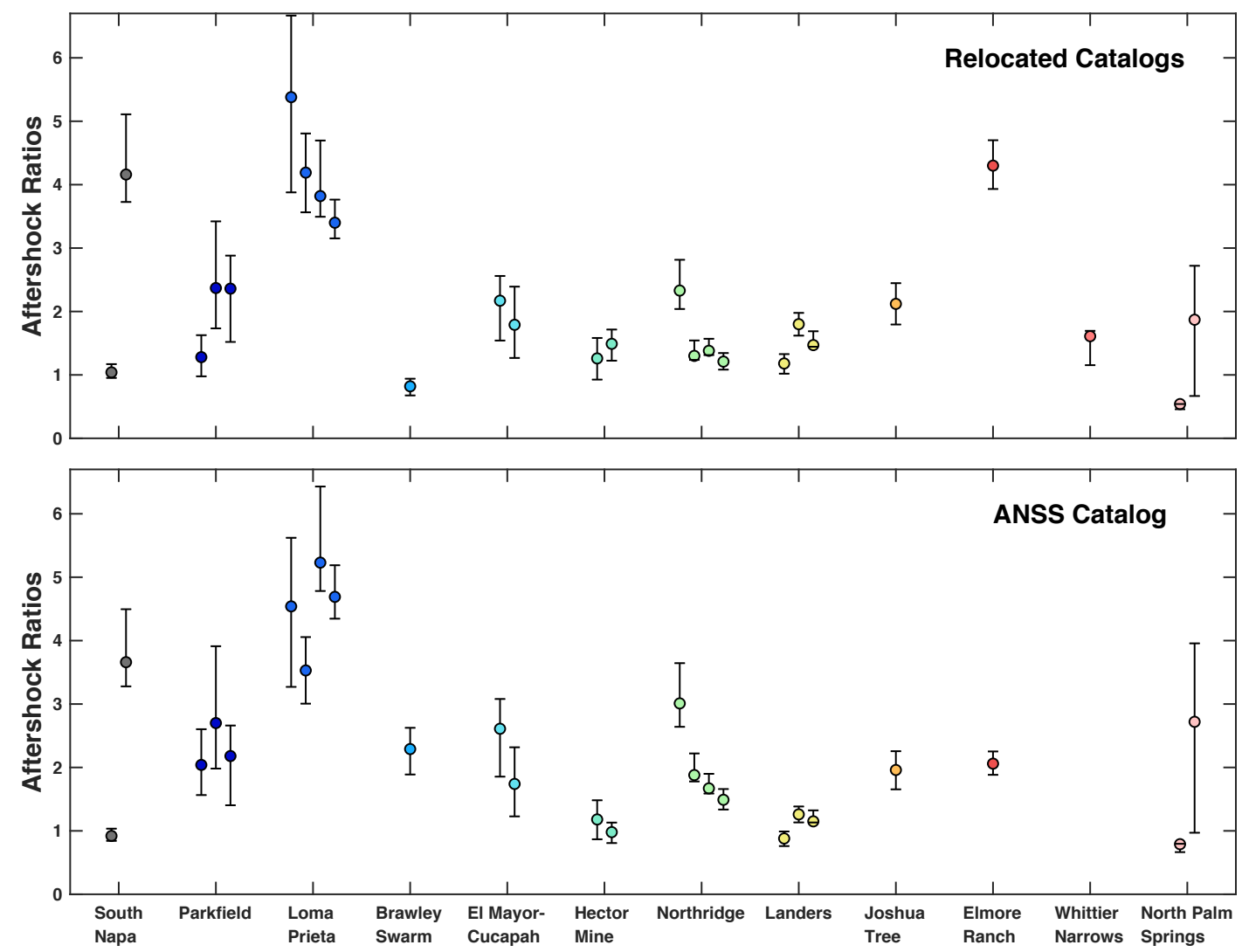

Earthquakes

738 Figure 6. Aftershock zone area ratios for different earthquakes using different earthquake catalogs. If there are multiple slip inversions for the same earthquake, the ratios are slightly offset so that they do not overlap. The error bars are calculated using slip contours of 0.1 and 0.2 of the maximum slip to calculate different rupture areas. (Top) NCEDC data is used to calculate the aftershock zone area for the first 3 earthquakes, while SCEDC data is used for the rest of the earthquakes. (Bottom) ANSS catalog is used. The ratio for the Whittier Narrows (WN) earthquake is not obtained from the ANSS catalog because the data does not yield a robust estimation of the magnitude of completeness. 

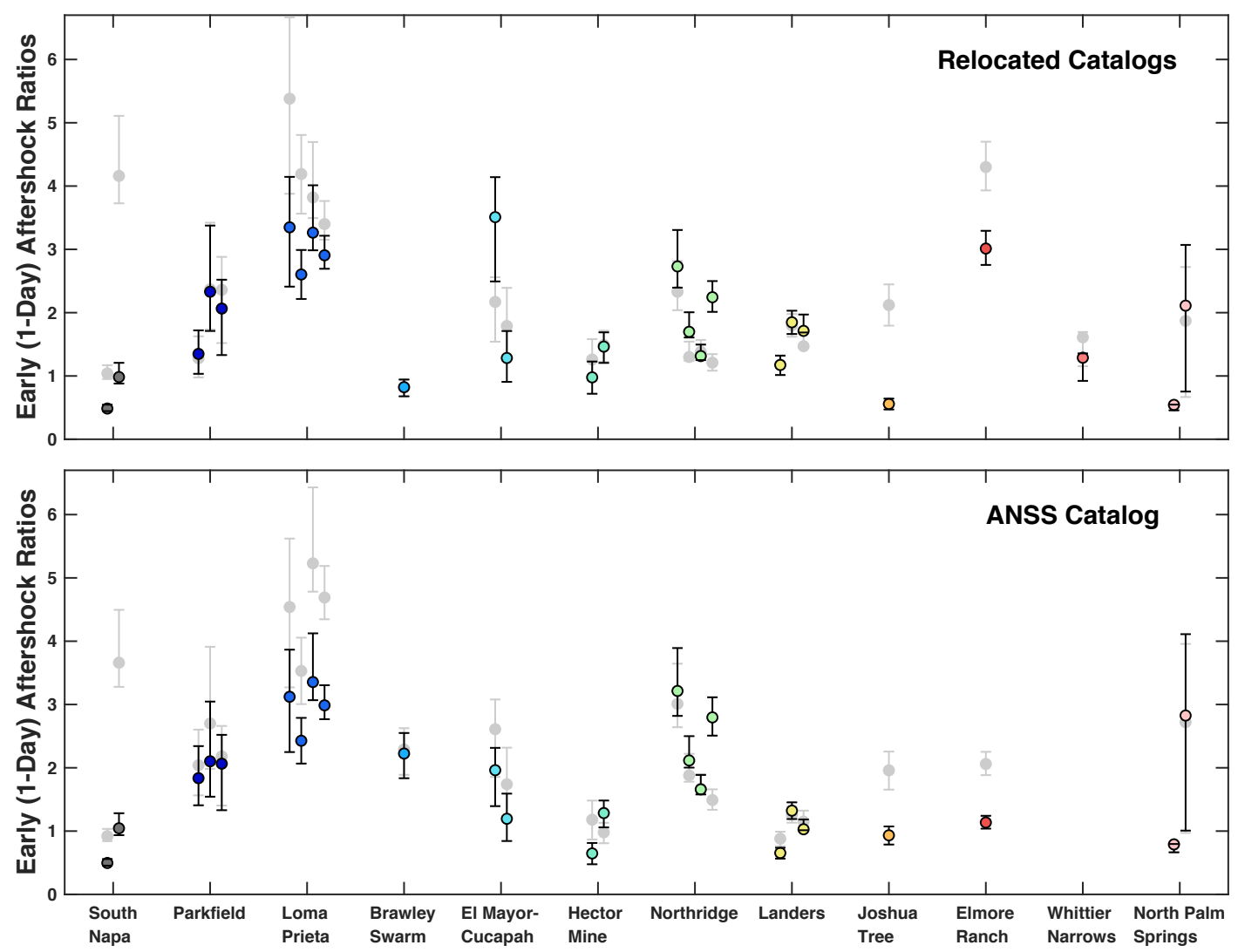

Earthquakes

748 Figure 7. Aftershock ratios calculated from 1-day aftershock durations for both earthquake catalogs. The 749 aftershock ratios for the whole duration is plotted in the background in light grey for comparison.

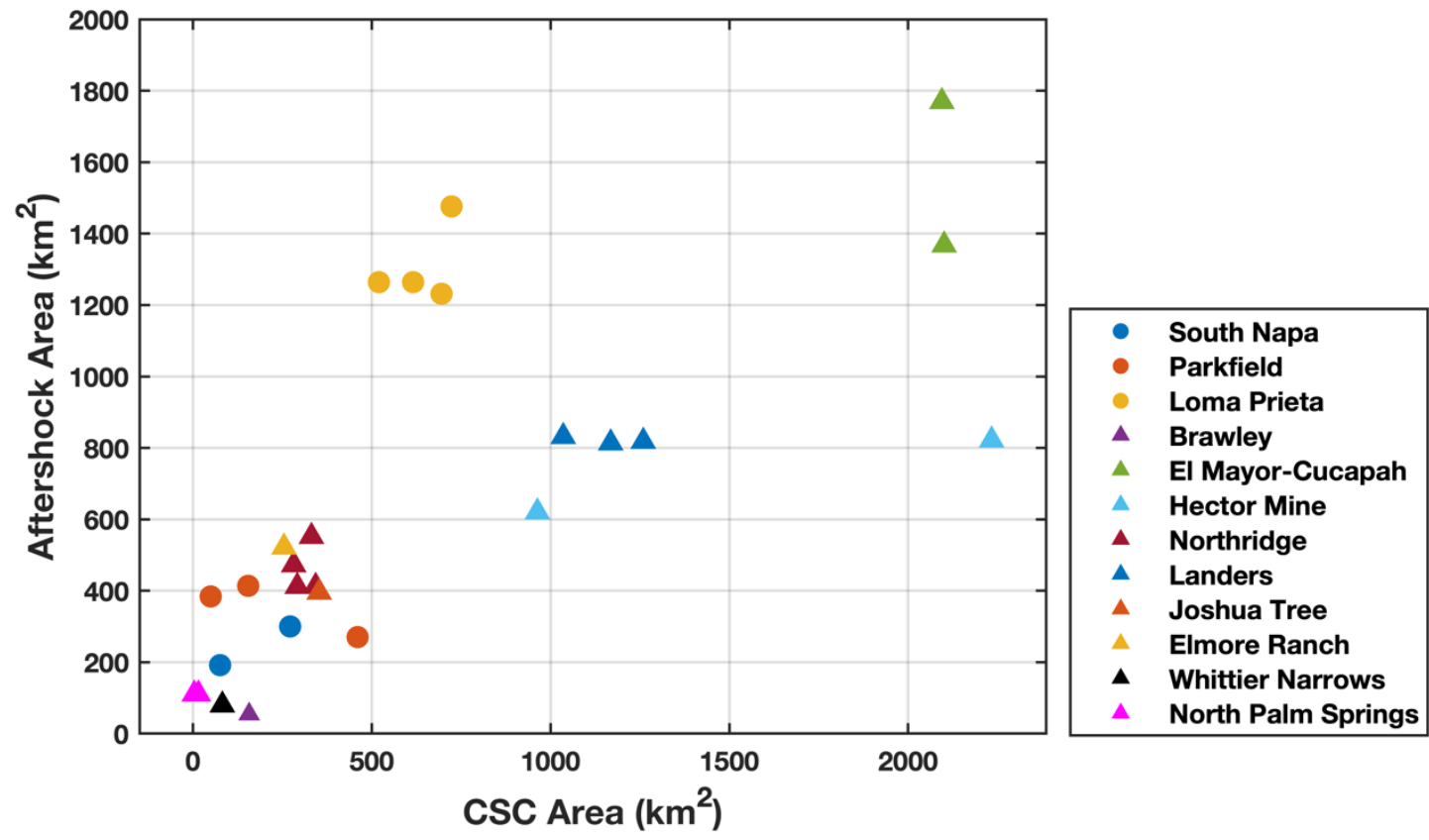

$751 \quad$ Figure 8. Aftershock zone area vs. Coulomb stress change area. 


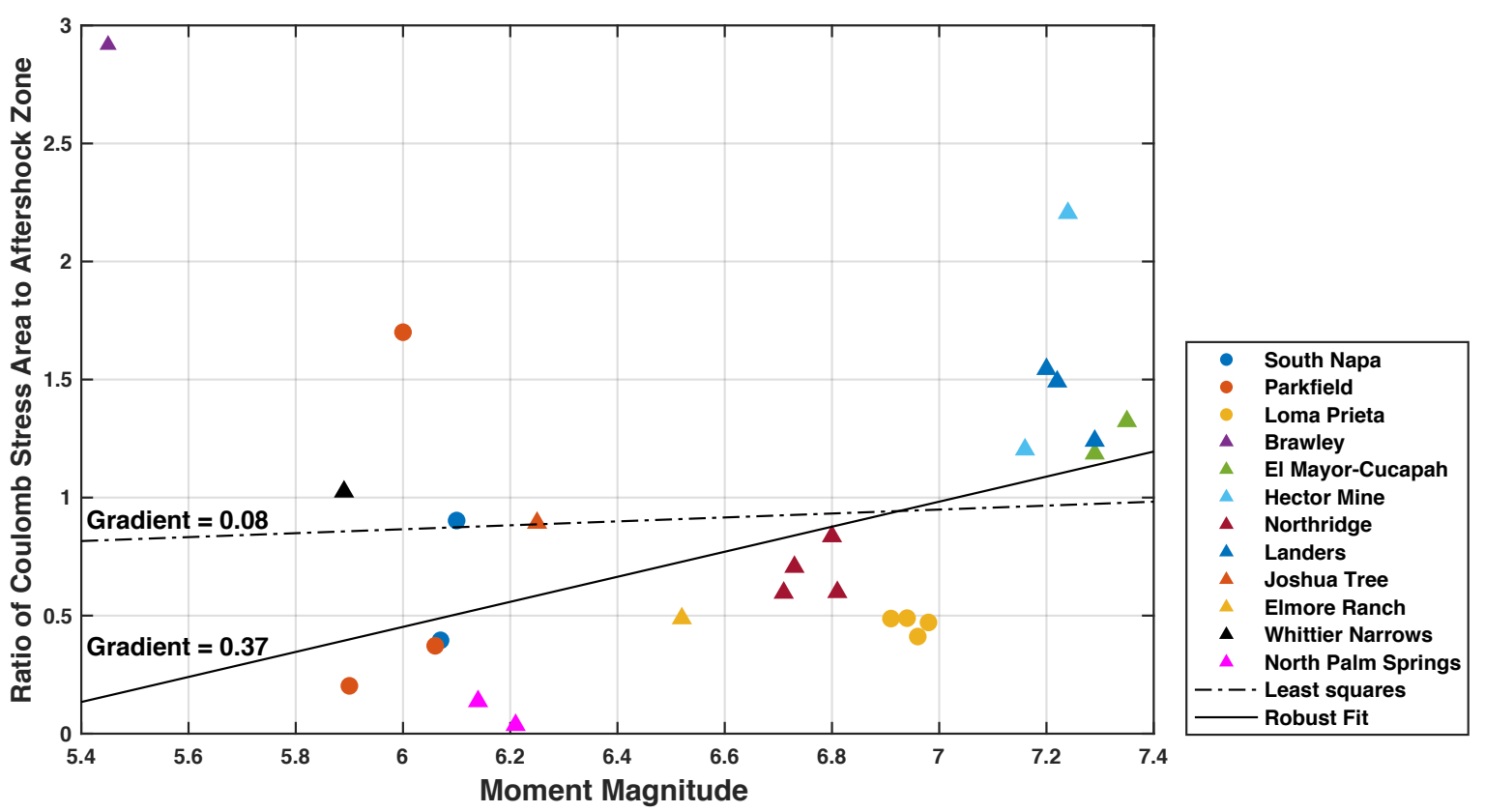

752

753

754

755

Figure 9. Robust fitting (solid line) and least squares fitting (dashed line) of ratios of Coulomb stress area to aftershock zone area with magnitude

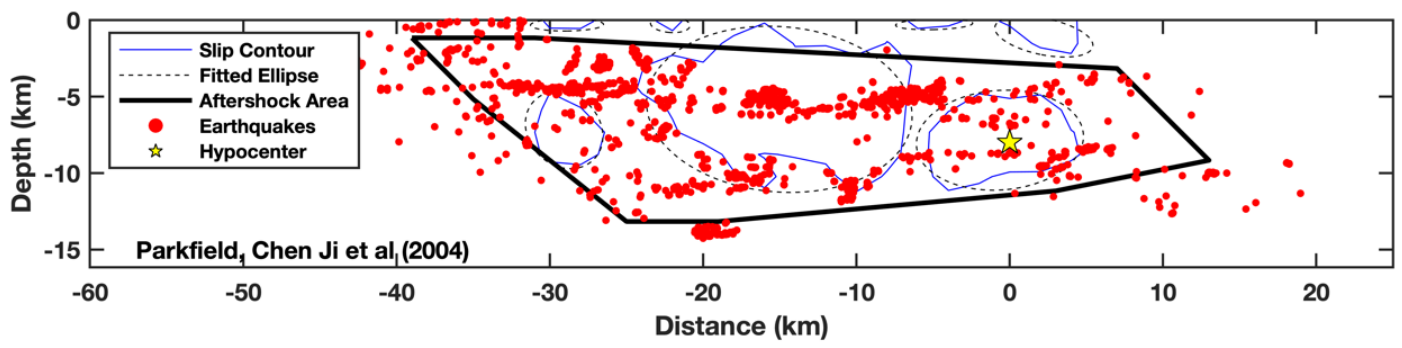

757 Figure 10. Illustration of how the distances from slip contour are calculated using the Parkfield, Chen Ji et 758 al slip model. 

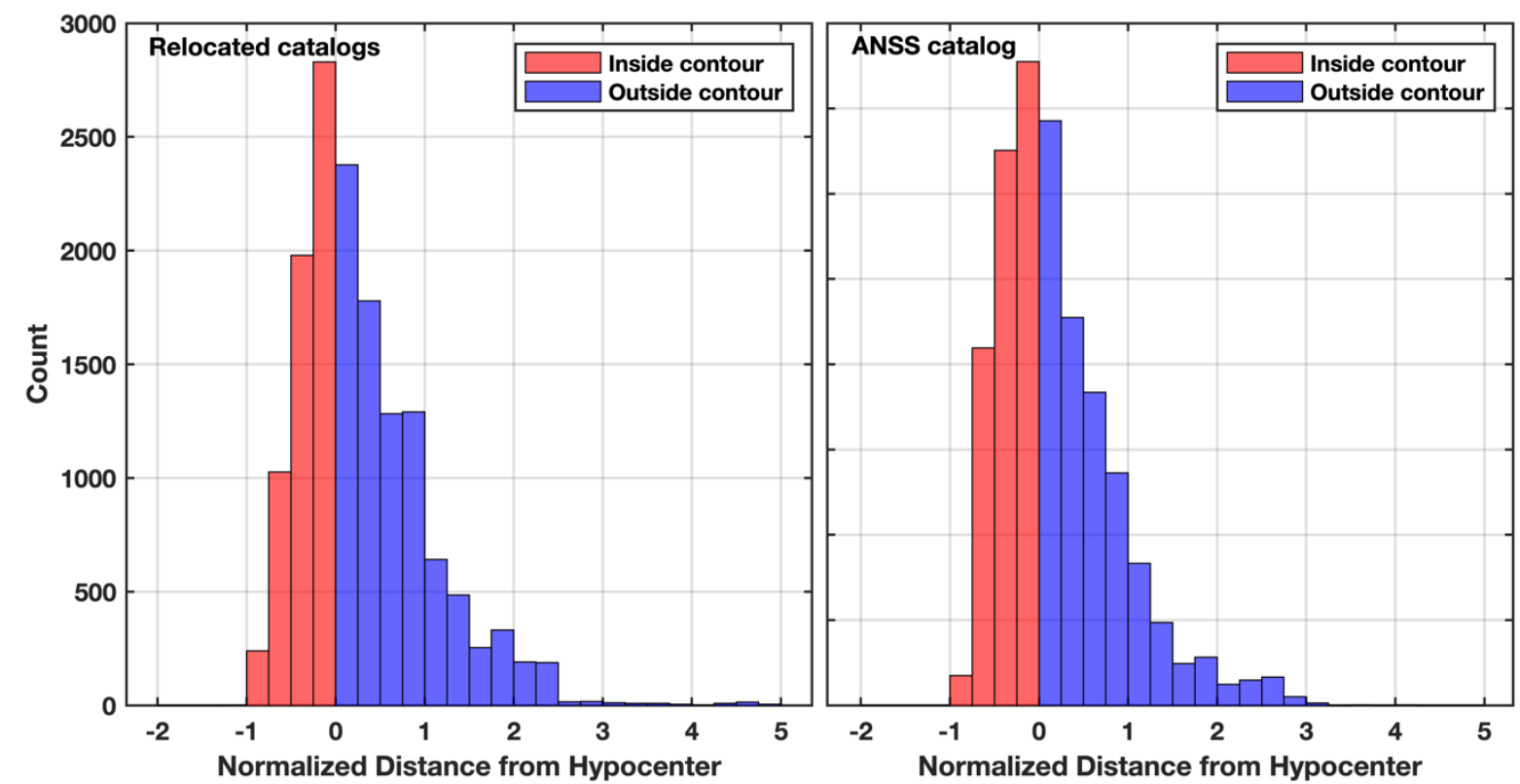

Figure 11. Histogram of aftershock distances from slip contours for all earthquakes using the relocated and 762 ANSS catalogs. 